\title{
Effect of temozolomide on survival in elderly patients with glioblastoma and impaired performance status: a propensity score-matching analysis [Corrigendum]
}

Liu Y, Liu P, Shao W, et al. OncoTargets and Therapy. 2017; 10:4029-4035.

On page 4029, the affiliation should read "Department of Neurosurgery, Affiliated Hospital of Binzhou Medical University, Binzhou, Shandong, People's Republic of China" instead of "Department of Neurosurgery, Affiliated Hospital of Binzhou Medical University, Binzhou, Shandong, Yantai, People's Republic of China".
On page 4029, the correspondence address should read "Department of Neurosurgery, Affiliated Hospital of Binzhou Medical University, Binzhou, Shandong, 256600, People's Republic of China" instead of "Department of Neurosurgery, Affiliated Hospital of Binzhou Medical University, Binzhou, Shandong, Yantai 256600, People's Republic of China".
OncoTargets and Therapy

\section{Publish your work in this journal}

OncoTargets and Therapy is an international, peer-reviewed, open access journal focusing on the pathological basis of all cancers, potential targets for therapy and treatment protocols employed to improve the management of cancer patients. The journal also focuses on the impact

of management programs and new therapeutic agents and protocols on

\section{Dovepress}

patient perspectives such as quality of life, adherence and satisfaction. The manuscript management system is completely online and includes a very quick and fair peer-review system, which is all easy to use. Visit http://www.dovepress.com/testimonials.php to read real quotes from published authors. 